\title{
Regional Cluster: Terminological Analysis of the Concept
}

\author{
Abdulazim Abdulrakhmanov ${ }^{1},{ }^{*}$ Rasul Magomedov ${ }^{2}$, Lukman Aigubov $^{3}$ \\ ${ }^{1}$ Dagestan Humanitarian Institute (branch) "Academy of Labour and Social Relations", Russia \\ ${ }^{2}$ Dagestan State Technical University, Russia \\ ${ }^{3}$ Dagestan State University, Russia \\ *Email:abdula0770@mail.ru
}

\begin{abstract}
The article considers and systematises theoretical approaches to determining clusters' nature and role in developing the regional economy. Based on the terminological analysis results, the cluster's main characteristics that underlie the definition of its essence are identified. These include the association (group) of interconnected enterprises; concentration by geographical or industry characteristics; competition; ensuring high competitiveness of products; synergy effect; cooperation; introduction of new technologies. To clarify the cluster's essence, the paper systematises scientists' views on its role in the region's economy. The author considered the effect of clusters at 3 levels: the enterprise (increasing competitiveness, sharing experience, increasing the level of specialisation, increasing turnover and product quality, etc.); state authorities (increasing budget revenues, reducing unemployment benefits, etc.); the economy of the region (reducing unemployment, improving the standard of living of the population, increasing the industrial, innovative, investment, and scientific potential of the region). The results obtained formed the basis for clarifying the essence of the concept of "cluster".
\end{abstract}

Keywords: Cluster, Group of enterprises, Competition, Role, Effect.

\section{INTRODUCTION}

There has been substantial scientific interest in the nature and role of clusters in the region's development in the last two decades. Nowadays, clusters have become an essential component of regional development strategies and innovative development in many countries worldwide. The concept of clusters is widely used in economic geography, innovation research, and related disciplines. Moreover, recent studies indicate a high relationship between the level of clustering of the economy and the indices of information and innovation development of the country [1]. The role of clusters for the economy is actively discussed in the modern literature, since, as the experience of developed countries shows, their functioning allows building effective relationships between enterprises, the state, educational institutions, public organisations and other cluster mechanism participants [2]. In this regard, the study of the nature and role of clusters for the country's economy and its regions is of particular relevance.

\section{RESEARCH METHODS}

During the study, the following methods were used: logical - dialectical (to justify the role of clusters for the economy of the region); synthesis and comparative analysis (to determine the essence of the cluster and identify specific characteristics); construction of analytical tables (to visually display the results of the study).

\section{STUDY RESULTS AND DISCUSSION}

The founder of the clustering theory, Porter M.E., believes that the fundamental motive for creating clusters is that the best conditions are created in industrial clusters to increase the competitiveness of products [3].

To date, there is no single definition of the concept of "cluster" among researchers. However, as shown in table 1 , most definitions have similar characteristics that reflect the essence of the term "cluster". 
So, all the authors agree that a cluster is, first of all, "an association (group) of interconnected enterprises". Simultaneously, some researchers reveal in more detail the companies that are part of the cluster. Thus, S.E. Savzikhanova [4] refers here to commercial and noncommercial enterprises, V.Yu. Yershova [2] organisations, communities, enterprises, educational institutions, and V.S. Fateev [5] and V. A. Kovalchuk [6] also adds state authorities to this group.

Another often-used feature is the "focus on geography" (mentioned by 10 of 11 authors), at least in the definitions found "concentration on a geographical or sectoral basis" (3 of 11 authors) and only V.Yu. Yershova [2] in addition to the territorial and sectoral components of the concept of the cluster, also reflects the economic and social characteristics that may underlie the association of enterprises. Nowadays, it should be noted that geographical concentration in several industries (especially those built on knowledge) is no longer as relevant as before.

The definitions also often contain such elements as" competition" and "ensuring high competitiveness of products", which in its essence is one of the tasks of forming a cluster. 8 of the 11 authors reviewed focus on them.

The "synergy effect", which is a means of increasing competitiveness, as well as" cooperation" are mentioned by the three (S.E. Savzikhanova, E.A. Bakhshyan and V.A. Kovalchuk) of 11 researchers. According to Bakhshyan E.A., Khasanova H.R., the main types of synergistic effects in clusters should be identified: knowledge exchange, cost reduction, investment attraction, infrastructure use, the introduction of new technologies, etc. $[7,8]$

It should be noted that only in 2 definitions (Yu.B. Mindlin, V.Yu. Yershova) the final goal of creating a cluster is the development of the region's economy, which significantly increases the value of these approaches.

Some authors focus on the "innovative" component of the cluster (for example, S.E. Savzikhanova, V.Yu. Yershova, E.A. Bakhshyan), which contributes to improving the competitiveness of the products produced.

After analysing the existing approaches to the definition of a cluster, we consider it appropriate to clarify its essence by reflecting the expected effect of forming a cluster for all its participants. For this purpose, the paper used and extended the approach of S.E. Savzikhanova [4] considers the impact of clusters at 3 levels: the enterprise; public authorities; the region's economy.

At the level of the region's economy, we denote:
- improving the competitiveness and efficiency of the functioning of the regions through the introduction of new technologies [9];

- overcoming narrow-industry trends in the development of the economy in the region [10];

- formation of a balanced regional development policy and more effective cooperation between science, government and business [11];

- increase, in addition to industrial, scientific, educational, investment and innovation potential of the region's economy;

- increased investment in the regional economy [12];

- increase in the gross regional product;

- increasing the profitability and region's living standard, ensuring employment of the population;

- stimulating the emergence of new firms that serve a specific market niche.

At the enterprise level:

- increasing the competitiveness of the enterprise;

- reduce costs and increase the level of quality of knowledge-intensive services due to the synergy effect and standardisation of approaches to quality, logistics, engineering, information technology, etc.;

- increase productivity and accelerate innovation;

- exchange of experience and technologies between companies, mutual training;

- training of highly qualified personnel in various fields;

- increase in turnover for cluster member companies through the development of joint products;

- increasing the level of specialisation of enterprises;

- increasing the level of protection of mutual interests based on maintaining stable and competitive principles;

- reduction of barriers to entry into the markets of products, supplies of raw materials, labour for small and medium-sized enterprises;

- expanding access to finance for small and mediumsized businesses due to the high business reputation of the cluster;

At the level of state authorities:

- increase the level of budget revenue within the cluster;

- reduction of unemployment benefits;

- increasing the level of decentralisation of the region; 
Table 1. Terminological analysis of the concept of "cluster"

\begin{tabular}{|c|c|c|}
\hline Author & The concept & Key Features \\
\hline Porter M.E. [3] & $\begin{array}{l}\text { A cluster is a geographical agglomeration of companies, } \\
\text { suppliers, service providers, and related institutions in a } \\
\text { particular area, competing in several areas, but working } \\
\text { together. }\end{array}$ & $\begin{array}{l}\text { - concentration by geographical feature; } \\
\text { - groups of related companies; } \\
\text { - competition; } \\
\text { - joint work. }\end{array}$ \\
\hline Lauren Young [13] & $\begin{array}{l}\text { Clusters are groups of companies either located close to } \\
\text { each other or belong to the same industry. }\end{array}$ & $\begin{array}{l}\text { - group of companies; } \\
\text { - concentration based on geographical } \\
\text { or industry characteristics. }\end{array}$ \\
\hline S.E. Savzikhanova [4] & $\begin{array}{l}\text { A cluster is an association of independent commercial and } \\
\text { non-commercial companies grouped at the resource level } \\
\text { to implement a common goal in a technological network } \\
\text { that provides achievement with a synergistic effect } \\
\text { sufficient to produce competitive products or services } \\
\text { focused on innovation within a single information and } \\
\text { communication space. }\end{array}$ & $\begin{array}{l}\text { - association of commercial and non- } \\
\text { commercial companies; } \\
\text { - technology network; } \\
\text { - achieving a common goal; } \\
\text { - synergistic effect; } \\
\text { - obtaining competitive products or } \\
\text { services; } \\
\text { - focus on innovation activities; } \\
\text { - formation of a single information and } \\
\text { communication space within the cluster. }\end{array}$ \\
\hline V.Yu. Yershova [2] & $\begin{array}{l}\text { A cluster is a group of organisations, communities, } \\
\text { enterprises, educational institutions, etc., united in one } \\
\text { conglomerate or association based on economic, } \\
\text { geographical, social and industrial characteristics, which } \\
\text { contribute to further development, increase } \\
\text { competitiveness and attractiveness, create and further } \\
\text { introduce new technologies to develop all areas in the } \\
\text { region effectively. }\end{array}$ & $\begin{array}{l}\text { - a group of interconnected enterprises; } \\
\text { - concentration based on geographical, } \\
\text { economic, social, and industrial } \\
\text { characteristics; } \\
\text { - increasing competitiveness; } \\
\text { - introduction of new technologies; } \\
\text { - effective development of the region. }\end{array}$ \\
\hline Yu.B. Mindlin [10] & $\begin{array}{l}\text { A cluster is a social concept formed in a community of } \\
\text { people or organisations with related economic interests. At } \\
\text { the same time, regions that have clusters on their territory } \\
\text { become leaders in economic development, and regions in } \\
\text { which they are not represented, in most cases, become } \\
\text { depressed territories. }\end{array}$ & $\begin{array}{l}\text { - community of people or organisations; } \\
\text { - related economic interests; } \\
\text { - economic development. }\end{array}$ \\
\hline E.A. Bakhshyan [7] & $\begin{array}{l}\text { Cluster - a set of economic entities located on the same } \\
\text { territory, striving for stability, relations between which have } \\
\text { a functional dependence, and having a synergistic effect } \\
\text { generated because of cooperation and competition, and } \\
\text { have a high level of innovation activity. }\end{array}$ & $\begin{array}{l}\text { - a set of economic entities; } \\
\text { - concentration on a territorial basis; } \\
\text { - the presence of a synergistic effect; } \\
\text { - mutual cooperation and competition; } \\
\text { - high innovation activity. }\end{array}$ \\
\hline $\begin{array}{l}\text { Federal Law No. 116-FZ } \\
\text { of July 22, } 2005 \text { "On } \\
\text { Special Economic } \\
\text { Zones in the Russian } \\
\text { Federation" [15] }\end{array}$ & $\begin{array}{l}\text { A cluster is a collection of special economic zones of one } \\
\text { or more types, determined by the Government of the } \\
\text { Russian Federation and managed by a single management } \\
\text { company. }\end{array}$ & $\begin{array}{l}\text { - a set of economic zones; } \\
\text { - they are managed by the same } \\
\text { company. }\end{array}$ \\
\hline V.S. Fateev [5] & $\begin{array}{l}\text { A cluster is an association of industrial enterprises, research } \\
\text { centres, financial and credit institutions, state authorities, } \\
\text { and public organisations formed based on territorial } \\
\text { associations of networks of major manufacturers, } \\
\text { specialised suppliers, and consumers connected by a } \\
\text { technological chain. }\end{array}$ & $\begin{array}{l}\text { - complex of enterprises, universities, } \\
\text { financial institutions, public authorities; } \\
\text { - territorial concentration; } \\
\text { - technological chain. }\end{array}$ \\
\hline Z.V. Prokopenko [16] & $\begin{array}{l}\text { A cluster is a spatial and economical form that has } \\
\text { emerged within the framework of an informal association } \\
\text { of several organisations, thanks to which the necessary } \\
\text { concentration of production, information, and } \\
\text { management infrastructure is achieved, which allows for a } \\
\text { high degree of competitiveness within a regional product. }\end{array}$ & $\begin{array}{l}\text { - spatial and economic form; } \\
\text { - informal association of organisations; } \\
\text { - concentration of production, } \\
\text { management, and information } \\
\text { infrastructure; } \\
\text { - ensuring the high competitiveness of } \\
\text { the regional product. }\end{array}$ \\
\hline V.A. Kovalchuk [6] & $\begin{array}{l}\text { A cluster is a geographically concentrated group of } \\
\text { interconnected companies (and related scientific } \\
\text { institutions and authorities) operating in the same or } \\
\text { related industries and ensuring a high level of } \\
\text { competitiveness and synergy in their overall activities while } \\
\text { maintaining internal competition. }\end{array}$ & $\begin{array}{l}\text { - a group of interconnected companies; } \\
\text { - concentration by geographical feature; } \\
\text { - ensuring high competitiveness of } \\
\text { products; } \\
\text { - synergistic effect; } \\
\text { - internal competition. }\end{array}$ \\
\hline O.M. Tishchenko [14] & $\begin{array}{l}\text { A cluster is a territorial-industrial, competitive-coordination } \\
\text { network of business structures, public organisations, and } \\
\text { scientific institutions that provide its participants with } \\
\text { competitive positions at different levels of national } \\
\text { economy. }\end{array}$ & $\begin{array}{l}\text { - association of business structures, etc. } \\
\text { organisations; } \\
\text { - concentration by territory or industry; } \\
\text { - ensuring competitive positions. }\end{array}$ \\
\hline
\end{tabular}


- development of the transport and information infrastructure of the business;

As a result of the creation of clusters, the efficiency of enterprises' functioning in the region increases, which is reflected in the growth of budget revenues and, ultimately, in improving the population's quality of life.

Thus, the cluster can be described as a set of interrelated companies (industrial enterprises, companies, scientific and educational centres, financial institutions, NGOs, public authorities) are combined on a territorial, sectoral, socio-economic, innovative and other characteristics, the result of which, due to synergetic effect is to increase the productivity and competitiveness of enterprises, improve living standards and employment, as well as, the growth of industrial, scientific, educational, investment and innovation potential of the economy of the region.

\section{CONCLUSIONS}

The study and systematisation of the cluster concept allowed us to make well-founded conclusions that the cluster concept is relevant in the current conditions of economic globalisation. Simultaneously, the analysis showed that economic scientists do not have a consistent point of view on the essence of the term "cluster". The paper highlights the main characteristic features of clusters and justifies their role in developing the region's economy, which served as the basis for a broader definition of the cluster concept. From the author's point of view, it is crucial to add the cluster's definition of its formation's expected effect for all its participants.

Based on the study results, a refined definition of the term "cluster" is proposed and systematic approaches to identifying the cluster's role at the enterprise level, state authorities and regional level.

\section{REFERENCES}

[1] A.M. Baranov, Formation of the Republic of Belarus's Information economy: New Prospects for Development, Bulletin of Economic Integration 2 (2015) 88-94.

[2] V.Yu. Yershova, The role of clusters in the development of the economy, Scientific research in education. Retrieved from: https://cyberleninka.ru/article/n/rol-klasterov-v$\underline{\text { razvitii-ekonomiki }}$

[3] M.E Porter, The Competitive Advantage of Nations, N.Y.: Free Press, 1990, 855 p.

[4] S.E. Savzikhanova, The cluster's role in developing the region's economy and improving its competitiveness, Russian Entrepreneurship 15(261) (2014) 1-8.
[5] V.S. Fateev, Clusters, cluster approach and its use as a tool for regulating the national and regional economy development, Bulletin of the Yanka Kupala State University of Grodno, Ser. 5, Economics, Sociology, Biology 2(131) (2012) 43.

[6] V.A. Kovalchuk, The essence of the cluster mechanism concept, Economic Bulletin of Donbas 3(33) (2013) 202-206.

[7] E.A. Bakhshyan, Clusters in the modern economy: essence, characteristics and generated effects, Theoretical and Applied Economics 1 (2019) 64-74 DOI: $\quad$ https://doi.org/10.25136/2409$\underline{8647.2019 .1 .28209}$

[8] H.R. Khasanov, The synergetic effect of the cluster. Retrieved from: http://www.meconomy.ru/art.php?nArtId=2784

[9] A.R. Akopyan, The role of clusters in developing modern national innovation systems of the world economy's subjects: thesis of $\mathrm{PhD}$ in Economics, 08.00.14, Moscow, 2016, 166 p.

[10] Yu.B. Mindlin, The leading role of clusters in the economy, Theoretical and Applied Economics 1 (2012) 1-5. DOI: https://doi.org/10.7256/2306$\underline{4595.2012 .1 .458}$

[11] C. Iordache, I. Ciochină, M.Asandei Clusters, Tourism Activity Increase Competitiveness Support Theoretical and Applied Economics Volume XVII 5(546) (2010) 99-112.

[12] O. Kuzmin, N. Stanasyuk, M. Olikhovska, Application of cluster approach to industrial potential development: innovative policy and management support, Economics, Entrepreneurship, Management, Lviv: Lviv Polytechnic Publishing House 4 (2017) 41- 48.

[13] E. Lawrence Young, Technoparks and clusters of firms. N.Y.: Free Press, 1995.

[14] O.M. Tishchenko, Clusters as a vector of economic development: organisation, essence and concepts, Theoretical and applied economics issues, Issue 21, K.: Polygraph, Kyiv University Centre, 2010, pp. 74-81.

[15] On Special Economic Zones in the Russian Federation, Federal Law of July 22, 2005, 116-FZ.

[16] Z.V. Prokopenko, Cluster strategy of regional development: essence, Advantages, Practice of institutional support, Regional Economy and Management: Electronic Scientific Journal, Iss. 4(48), 2016. Retrieved from: https://eeeregion.ru/article/4846 